\title{
The specifics in the work of social workers when rendering social services at the person's home
}

\author{
Rita Raudeliunaite \\ Mykolas Romeris University, Vilnius, Lithuania
}

\begin{abstract}
The objective of the study is to highlight the specifics of the work of a social worker when rendering social services at the person's home on the basis of the experience of social workers. Qualitative research strategy was used, including semi-structured interview.

The study revealed a wide spectrum of the activities of the social worker when organising the provision of social services at home: the identification and assessment of the need for a service, the planning, provision, coordination and assessment of the assistance or care at the person's home, the involvement of the service recipient in decision-making, the involvement of close relatives of the service recipient, teamwork, cooperation with other institutions, and improvement of skills of the employees.

The study revealed the benefit of social services at the person's home to the recipients of the services: living at their homes, they do not feel so lonely, they feel safe, needful, capable of benefiting from the needed assistance.

Difficulties, which arise when cooperating with the recipients of social services at home, are the following: people provide false information when identifying the need for a service, mental disorders of the service recipient, dissatisfaction with the rotation of the visiting care workers, complaints regarding the lack of communication. Organisational limitations of bodies providing services are linked to formalism, shortage of the staff, time restrictions for services, lack of transport, unavailability of services due to the limited financial resources of service recipients.
\end{abstract}

Key words: social services, home, elderly people, persons with disabilities, social worker.

\section{Introduction}

Recently, while improving social services system, ways are sought how to bring them closer to the person, so that the persons in need of social assistance would receive necessary services at their home or community thus remaining, as long as possible, in the social environment they are accustomed to [1]. Social services in the community and at the person's home are appreciated due to the increasing social security and social cohesion and reduced impact of stigmatisation [2]. It is recognised that social services in the community and at the person's home enable the person to live with dignity and maximal autonomy at their home rather than be separated from their community $[3,4]$.

In Lithuanian social policy, social services at home are identified as a priority. The Law on Social Services [5] emphasises that social services to elderly people should be provided creating conditions that enable the person to live at home with their family, to handle household activities independently as long as it is possible. It means social service should organize assistance which enables the person in need to retain social relationships with his family, the closest people and society, i.e. to reduce social exclusion. 
Social services to the person with a severe disability must be provided while securing a safe and healthy environment, assistance adequate to the person's dignity which is harmonised with the person's healthcare, permanent care and permanent assistance. The Provisions of the Expansion Directions of Social Services at Home and the Enhancing of Efficiency in Residential Care [6] maintain that one of the most important social services in the community has to be social services at home, because they improve the life quality of people who are unable to take care of themselves, assist a person in remaining in a domestic environment, provide an opportunity to assess individual needs of the person and to provide him with the most necessary social services, and they are the most cost efficient kind of social services. The provisions underline that while expanding the system of social services at home it is necessary to provide various kinds of social services at the person's home, to create an integrated system of assistance at home by merging the services of primary health care in the community with the provision of social services at home, as well as by involving non-government organisations and non-formal service providers in the provision of social services at home. The experience in the European Union countries shows that providers of assistance at home, ensuring conditions to people with disabilities and the elderly to live in their homes as long as it is possible, must provide complex assistance [7]. Only by developing a unified structure of health care and of the network of social service it is possible to effectively create integrated assistance compatible with the needs of the people who are taken care of at home. Various services provided at home may improve the life quality of the elderly and persons with disabilities, to save state funds allocated to residential care of these persons.

In provision of social services at person's home an important place is taken by home help and social day care services at home. Home help is services provided at person's home assisting a person (family) in managing household activities and participating in the life of society [8]. It is a service which does not require continuous care of specialists. Social day care at the person's home is complex assistance requiring continuous care of specialists provided to a person during the day at their home.

Every year the increase of the recipients of social services at home is noticeable. According to the data of The Lithuanian Department of Statistics, in 2016, home help and social care services at the person's home were provided to 18.6 thousand people, or to 4.5 per cent more people than in 2015 [9]. There is a tendency observed that the majority (82.2 per cent) of persons, who received social services at home, were retired, 16.6 per cent of them were working-age persons with disabilities, 1.2 per cent of them were children with disabilities [9].

In accordance with the Law on Social Services [5] municipalities are responsible for the provision of social services at home. Municipalities take care of the development of the infrastructure of social services, provide for the mechanism of supply of social services at the person's home, allocate financial means for social services in their budget, and assess the needs of persons for social services and assign relevant services for a person. The studies have shown that the establishment of the system of social services at home and its development is relevant and necessary. Annual Audit Report [10] states that, although the demand for social services at home is rising, the present infrastructure of social services in the municipalities does not satisfy an increasing demand for social services at the person's home. Due to undeveloped infrastructure of social services provided at the person's home and the lack of appropriate selection criteria for a service when assigning a social care service for a person, services giving a person the possibility to stay at home as long as possible are not regarded as a priority. Consequently, the longest waiting lists in social care institution are for the services of long-term social care. The report states that there is the lack of qualified personnel providing social care and day care services at the person's home, which is having a negative effect 
not only on accessibility to services, but also on the quality of provided services. This shows that the problem of the provision of social services at home is topical and requiring systematic research that helps reveal the experience of the provision of services at home. This would help to identify the positive aspects of social services provided at home and emerging problems and possible approaches for solving them assisting in improving the system of organising and the provision of services at home in order to ensure the quality of social services at home.

It should be pointed out that, although social services at person's home are given priority, in Lithuania, research on the subject has not been conducted. The analysis of scientific literature revealed that scholars have drawn a great deal of attention to the problem of the quality of services [11-14], the management of social services and the effectiveness of services and the problem of the cost reduction of services [2, 16-18], the expression of empowerment in the context of social services $[19,20]$. In the context of the aforementioned studies, the problem of social services at home, as one of the priority areas of change in social services system is highlighted. One of the forms of social services at home - home help was investigated by V. Indrašienė and A. Katkonienè [21] more in-depth. The accessibility of social services at home was revealed by the of study ofI.Tamutienè and R. Naujaniené [22]. R. Raudeliūnaitè and A. Smalcer [23] analysed the assessment of the provision of social services at home based on the experience of service recipients. A substantial part of studies has been focused on the problem of integrated health care and social services at home [7, 2426].

The study brings up a scientific problem which is formulated by the following question: What social work specifics and emerging problems when providing home help and social day care services at the person's home are identified by social workers?

The objective of the study is to highlight the particularities of the activity of a social worker when providing home help and social day care services at the person's home based on the experience of social workers.

\section{Research methods}

The strategy of qualitative research was used. Semi-structured interviews were conducted. The analysis of the results was performed by applying the method of content analysis: the text was read and essential aspects, which were reflected in phrases, sentences and words directly related to phenomenon under the investigation, were identified; the identification of notional elements in the read text; the breakdown of notional elements into categories and subcategories; the integration of categories into the context of the analyzed phenomenon and the description of the content [27].

The research sample. The targeted selection type of the researched ones was chosen. The main selection criteria for the research participants were no less than three years experience of social work providing home help and social day care services at the person's home. 10 social workers took part in the research.

Research ethics. The research was conducted without violating the rights of the research participants and in conformity with the principles of research ethics: the participation of the informants was voluntary; the research participants were sensitized to the goal of the research, the method of data collection; their confidentiality was ensured. In order to ensure the confidentiality of the research participants, their names were encrypted by assigning a letter to them. 


\section{Research results analysis}

During the study we tried to reveal the particularities of the activity of social workers when providing home help and social day care services at person's home. When analysing the findings four qualitative categories became apparent: the characteristic of the service recipient, activity areas of a social worker when organising the provision of services at the person's home, the benefits of provided services to service recipients and difficulties arising when providing services at person's home.

Category "The characteristics of the service recipient". Social workers, when characterising the recipient of social services at home, pointed out that most often they are lonely elderly persons in a frail state of health, who have difficulty taking care of their own life independently, they need the assistance of other people to live independently at home: "the most typical recipient of services at home is an elderly person, who due to health problems is unable to take care of themselves and needs the assistance of other person" (A). Such portrait of the recipient of social services is attributable to changes linked to demographic ageing: the population of older people is growing, especially the number of the elderly people who are older than 80 [26]. On the basis of the forecast of the Statistical Office of the European Union (Eurostat), it is considered that, in the beginning of 2060, almost 37 per cent of Lithuanian population will consist of the elderly (65 years old and older). Consequently, the demand for social services will also rise, and that is a significant challenge to the organising system of social services of the state - it must adjust to the increasing demand for the services, to reorganise the present one or to develop a new infrastructure of services.

The informants pointed out that social services at person's home are also provided to other groups of persons, as provided for by legislation: adult persons with disabilities, children with disabilities and other persons, who have lost their independence due to an illness or other reasons and to whom the need for a service was identified.

The category "Activity areas of the social worker when organising the provision of social services at home" is further specified by the content of the distinguished subcategories: need identification and assessment; assistance planning; the provision of assistance, the assessment of support, the involvement of the service recipient in decision-making, promotion of activity of the service recipient, the involvement of close relatives of the service recipient, teamwork, cooperation with other institutions and organisations, and improving of skills of the employees.

The social workers emphasised that they, while providing social services at person's home, are guided by the procedure descriptions and service specifications regarding home help and social day care at person's home approved by municipalities. The informants pointed out that, in order to receive home help or social day care services at the person's home, a person or his guardian has to apply at the municipality's centre of social services, to complete an application for social services and to provide necessary documents. The participants of the study also pointed out that "as provided for by legislation, other persons are also able to contact respective institutions requesting the provision of home help or day care, to point out the reason why a person himself is not able to do that, a question regarding services is also discussed without the person's request when information is received on the necessity of social services for a person from the police, health care, social service institutions and other institutions" (E).

Social workers perform the identification and assessment of a person's need for services. The informants pointed out that the need for social services at home is identified and assessed individually and in a complex way, taking into account the person's health condition, independence, life and household conditions and the possibilities of the family members to 
help: "We evaluate what the client can do, how their environment is able to assist, whether there are relatives, what they can do, whether they have none of them and the like (A)". In the opinion of the participants of the study, the identification and assessment of needs ensures that the recipient at home receives services adequate to their condition. The informants told that, while assessing the person's needs, they sought to obtain the largest possible amount of information on the recipient of social services at home: "I am never in a hurry and pursue the detailed examination of every detail and triviality related to the client" (D). Exhaustive and comprehensive assessment enables a social worker to know the service recipient's situation better, to meet their needs. It is noteworthy that the social worker reviews the person's need for social services during the provision of social services, in the event of changed circumstances or the condition of the person's health.

A decision regarding the assignment of social services is made basing on the application of a social worker who identified the person's need for social services in line with the procedures established by the institution of the municipality. After the decision to assign social services has been made, a contract of service provision with a service recipient is concluded. The further activity of the social worker must be associated with the provision of services at the person's home. It is noteworthy that services, provided at person's home, in accordance with the laws of the Republic of Lithuania, are paid, free or partly paid. Every municipality approves the price list of such social services and payment mechanisms for services. Financial capacity of the person (family members) is assessed by social workers simultaneously with assessment of person's need for home help or social day care.

The social workers pointed out that service specifications of home help and social care at person's home foresee a wide spectrum of services: the provision of information and consulting, mediation and representation, communication, organising of catering, assistance with housework and domestic activities, organising of personal hygiene services, organising of health care, the development and maintenance of daily life skills and other services. Assistance is provided in accordance with the approved list of home help services in which service specifications are provided, the duration of their provision and prices, a visiting care specialist is appointed to provide services at home. The informants pointed out that, in accordance with the description of social day care provision at person's home approved by the municipality of their town, day care is provided from 2 to 8 hours per day up to 7 times per week. Those persons, whose adult children, adult grandchildren or heirs of the property live in that town or district, are provided with day care from 2 to 8 hours per day up to 5 times per week. In accordance with the Social Service Catalogue [8], the duration of social home help is up to 5 times per week.

The assessment of provided services is an important part of the provision process of social services at person's home. Assessment, according to the social workers, helps identify whether the person is satisfied with the provided service, what problems they encounter, what changes have occurred in their situation: "We see that the person's health is deteriorating, the situation is changing, and they are already not able to do some things, then we reassess their need (B)". The social workers noted that they endeavour to maintain permanent communication with a service recipient, to receive feedback from them: they phone, visit their clients, provide information, consult, discusses how the foreseen services are provided, what questions, uncertainties, problems arise to them. According to the informant, "there is a continuous communication, most often over the telephone. We inform clients regarding everything: changing schedules, service staff, time changes regarding service provision, what we can do in order that they would be satisfied, what he can do in order that any miscommunication, misunderstandings and the like would no longer occur" (A). Meetings and individual conversations with visiting care specialists are organised while discussing 
various aspects of service provision, problems which have arisen: "We talk to the staff. Every morning we organise short meetings. We start with the discussion on the previous day, what happened, what observations are there, what clients asked for. We talk individually with the employees" (B). According to L.C. Johnson [28], assessment is a recurrent part of the social work process and the means to ascertain whether desired objectives and tasks have been achieved.

According to the contemporary approach to social work, the recipient of social services is not only a passive user of social services, but also an active participant. Consequently, it is important to develop collaborative relationships with the client by involving them in the provision of the service. Social services are inclusive only if an institution providing services and its employees (providers) create conditions to a service recipient, the members of his family or guardians to get actively involved in the planning, decision-making and assessment of the provided services. Such participation in the provision process of social services enables the recipients of social services to recognise and identify their needs on their own and to control personal changes [20]. The study revealed that service recipients actively participate and express their opinion, make decisions at all stages of service provision starting from the assessment and identification of the need for a service and finishing with service assessment.

Activeness promotion in a service recipient is equally important. When analysing the findings of the study, it came to light that service recipients, while taking into account the level of their independence and health condition, are encouraged and involved in all possible activities: cooking, the tidying of their flat and the like. When providing services it is sought that a service recipient would not be passive, would not be rendered powerless: "there are clients who are passive, for example, when asked what they want to buy in the shop today, they respond - "open the fridge and see what is missing". So we ask that there would be no such things. That the person would get ready beforehand and would think over what he needs. In so doing we encourage him to take care of himself" (A).

Social workers cooperate with the family members of the recipient of social services or other relatives. The participants of the study revealed that the involvement of close relatives of the service recipient and cooperation with them takes place from the very first visit of the social worker at home: "When identifying the need I always contact the children. If there is a possibility, I even invite when identifying the need. Then we come to a joint conclusion and make decisions together. After that there is a continuous cooperation with the client's relatives, and I encourage them to respond very much (E)". According to M. Berg-Weger [29], family members have the greatest knowledge of their relative and perform the most important role - they take care of him. The more people a person has in their close social network and the more diverse roles they perform, the higher the likelihood for support.

In the opinion of the social workers, the provision of social services at home is the result of teamwork. According to the participants of the study, teamwork is based on the pursuit of a common objective and responsible implementation of the tasks entrusted to each one, consultation, trust, the provision of assistance to each other, the development of positive mutual relationships. Teamwork, according to the informants, "offers new ways of looking at a problem and allows us to help a person in a more diverse way" $(\mathrm{H})$. In addition, in a team it is possible "to make faster and better decisions, to improve the client's situation in the most appropriate manner" (F). Researchers say that a successful cooperation is the result of good relationships between team members, mutual trust, respect and understanding. Such relationships create an important and valuable assistance network for service recipients [30]. The social workers pointed out that team meetings, during which "everyone has an opportunity express themselves, to say what they think" (C), are organised. The study revealed that team meetings take place in various ways. Shorter meetings take place every 
day, most often at the beginning of a working day. During them, current matters are discussed, information is shared, problems, which have arisen, are discussed. The main team meetings usually take place every two weeks, if need be, even more often. During them, the main work matters are discussed, more complicated events are analysed. The social workers clarified that, during meetings, not only problems are solved, but also their prevention is discussed: "We discuss it openly in order not to repeat the same mistakes again, because the employees have to go to work being safe and knowing what to do, this is my daily task (D)".

The participants of the study pointed out that when organising and providing services at home they cooperate with health care establishments, state institutions and non-governmental organisations, or communities. The informants maintained that the vast majority of all the recipients of social services at home are elderly people with disabilities and various health problems, therefore, cooperation with medical institutions, while helping them to solve health problems, is very important. The social workers also mentioned that they have to cooperate with such organisations like Caritas, the assistance service of the Order of Malta and charity and support fund The Food Bank: "We have clients with a very small income, and then the assistance of these organisations is badly needed (E)". The social workers noted that a community also plays an important role in the assistance network when small and big problems have to be solved or daily human concerns addressed: "When the person is lonely we can count on their neighbours or the chairman of the block of flats/community of the block of flats or the chairman of a local community $(\mathrm{H})$ ".

The social workers identified the competence of workers as one of the factors determining the provision of quality services: "The whole quality of work depends on the educational level of the worker, their abilities and knowledge, practical experience, continuous professional development" (D). Consequently, the informants deem the improvement of professional qualifications an important area of their professional activity. Social work is a multidisciplinary profession requiring significant knowledge, abilities and skills. In order to ensure professional assistance, the development of the workers of social services in different areas is necessary. They must continuously update their knowledge, skills, apply new work methods, and develop their need to continuously improve the existing competences. The findings of the study revealed that social workers improve their professional qualifications in various ways: by participating in trainings, courses, conferences, sharing good practice and novelties with their colleagues, consulting with other specialists.

When analysing the findings obtained during the study, the category "the benefits of the provision of social services at home to recipients" and four subcategories: a person lives at their own home, life quality improved, they feel safer, not so lonely - were highlighted.

The social workers emphasised the benefit of social services at home to services recipients. They noted that services provided at home enable service recipients to live at their home. The informants maintained that the majority of service recipients, "although their health is frail, and they have retained a small degree of independence, but they do not want to set off from their home", "...home is home, they feel best there, familiar environment, people they are familiar with” (A). According to E.L. Siegler, S.D. Lama, M.G. Knight, E. Laureano, M.C. Reid [4], when providing social services at home, conditions, which are created for the recipients to remain at their home, in their communities as long as possible, enable them to avoid institutionalisation and to reduce their social exclusion.

The social workers, who participated in the study, pointed out that services which are provided at home, make the life of service recipients easier, improve the quality of their life, because due to their precarious health, and reduced independence they find it difficult to satisfy their basic needs, to live a full-fledged life. The informants noted that, while receiving services at home, service recipients feel less lonely, have a sense of safety that 
others are in need of them, have awareness that they are able to receive assistance they need.

The social workers, organising the provision of social services at home, encounter various kinds of problems in their daily activity. When analysing the findings of the study, two qualitative categories came to light: difficulties arising when cooperating with recipients of social services at home and organisational limitedness of providing institutions.

The category "Difficulties arising when cooperating with recipients of social services at home" is made more concrete by the following distinguished subcategories: the provision of false information when identifying the need for a service, health problems of a service recipient, dissatisfaction with the rotation of visiting care workers, complaints regarding the lack of communication.

The social workers, who participated in the study, revealed that there are cases when the person applying for social services at home provides false information for the assessment of the need for social services in order to receive a service: "when assessing a need certain difficulties arise, because future clients make significant efforts to conceal the truth, the majority of them manipulate that they cannot do this or that, and when the contract is concluded and when we already start to provide services, it turns out that they can do both this and that $(\mathrm{G})$ ". The informants maintained that, if it turns out that a person provided false information, the provision of a service is discontinued until, taking into consideration new circumstances which came to light, the need for a service is re-identified.

The participants of the study mentioned health problems of a recipient of social services as reasons impeding collaboration between workers and service recipients. The participants of the study explained that most often difficulties arise in the case of people with mental and memory disorders. Difficulties with people with mental disabilities arise due to insufficient knowledge of workers how to work with these persons, this often leads to various misunderstandings and conflicts. The informants maintained that memory disorders of a client also impede work, for example, "A person does not remember where they put their money, how much of it they gave to workers, because of that disagreements and complaints occur that attempts are made to deceive them and the like." (E).

When analysing the information, which was obtained during the interviews, it has been observed that all the social workers, who participated in the study, noted that services recipients often complain of the lack of communication. The independence level of the recipients of social services has declined, therefore, they spend the majority of their time at home, and they would like that the workers of visitation care would spend more time to communicate with them. The social workers associate the lack of communication with service recipients with heavy workloads of the workers of visitation care and inability to give more time to communicate with a client.

The social workers pointed out that the recipients of services at home are dissatisfied with frequent changes of workers providing services to them. The participants of the study explained that frequent turnover of workers causes inconveniences for service recipients, because they need to explain their desires and wishes to a new worker every time. Another reason for the dissatisfaction of service recipients regarding the turnover of workers is the accustomedness of service recipients to one person and the appreciation of relationships with him. The informants maintained that it happens that after the change of a worker some clients begin as if to mutiny, to continuously complain that "the worker, who has newly come, does everything in a different manner than the previous one, therefore, they are dissatisfied (D)". Scholars revealed similar tendencies when full satisfaction of the recipients of social services at home with the provided services is impeded by frequent turnover of workers providing services [31]. 
When analysing the findings of the study a category "Organisational limitedness of service providing institutions" and four subcategories were distinguished: formalism, shortage of staff, restriction on the service time, the lack of transport means, services are not affordable due to limited financial resources of service recipients.

The social workers have noticed that, although all the documents, which they have to fill in are important, according to their words "red tape", burdens their work, because it is very time consuming and less time is available to communicate with their clients: "We spend loads of unnecessary time on paperwork, to enter data into one or another database and the like, I would rather visit people to fill that gap of their communication" (B).

The social workers mentioned that difficulties also arise due to staff shortage: "It is sometimes hard when in organising services there is a staff problem, when only three out of five work, because of illness, whereas we cannot tell a client that somebody is ill, and we will not come" $(\mathrm{H})$. Due to staffing problems, social workers are compelled to increase the workload of visitation care workers.

Another obstacle identified by the social workers is that when services are provided at home limited time is allocated to provide them per week and the time is not sufficient to meet the needs of services recipients. Because of that, according to the informants, they must "decrease the amount of some services somewhere not because they are not necessary for a person, but because their time is limited" (I).

The social workers pointed out that difficulties arise when organising transport services. According to them, to serve the whole large town, only three automobiles were given, therefore, the recipients of social services at home must order transport a few weeks in advance: "There is a shortage of transport services, because it depends on the finance supplied. We have 3 cars to serve our town, those cars break, drivers get ill, without mentioning fuel..." (A).

The study revealed that services are not affordable due to limited financial resources of the service recipients, which is one of the obstacles due to which the recipients of services at home refuse a service they need: "due to financial possibilities they even restrict themselves to food fetching once per week. To tell the truth, they would use many of services, because they are necessary, but they can hardly afford that for themselves (C)". Similar tendencies were revealed by other studies [22] which demonstrate that services at home, which are necessary to the recipients of social services, are unaffordable due to financial difficulties. Therefore, the recipients of services are prone to refuse services or to choose only the most necessary services.

\section{Conclusions}

Social services at person's home are one of the most progressive forms of social services. An important role, when rendering social services at person's home, is played by domestic assistance and social day care services at person's home. Domestic assistance is the entirety of services by which the person is provided with integrated assistance which does not require continuous oversight of the professionals. Social day care at person's home is the entirety of services by which the person is provided with integrated assistance, which require continuous oversight of the professionals during the day. Social workers play an important role when organising the rendering the services of domestic assistance and social care at person's home. The main recipients of domestic assistance and social day care at person's home are elderly people and persons with disabilities.

The study revealed a wide spectrum of the activities of the social worker when organising the provision of social services at home: the identification and assessment of the need for a service, the planning, provision, coordination and assessment of the assistance or care 
at person's home. The social worker, while organising the provision of the services at person's home, engages the recipient of a service in the decision making when identifying and assessing the person's need for the services, foreseeing and assessing the services, making a decision regarding the continuity of a service. When providing services at person's home the social worker promotes the activity of the recipient of a service, cooperates with the closest people of the recipient of a service, the employees who provide services, various bodies and organisations, communities. Social workers improve their professional qualification by participating in trainings, professional development training courses, conferences, exchanging good practices and innovations with their colleagues, consulting with other specialists.

The services, which are provided at person's home, allow the service recipients to live at their homes, they do not feel so lonely, they feel safe, needful, capable of benefiting from the assistance they need.

Social workers, who organise the provision of social services at home, in their daily activity encounter difficulties, arising when cooperating with the recipients of social services at home and organisational limitations of bodies providing the services. Difficulties, which arise when cooperating with the recipients of social services at home, are the following: people provide incorrect information when identifying the need for a service, mental disorders of the service recipient, dissatisfaction with the rotation of the workers of visiting care, complaints regarding the lack of communication. Organisational limitations of bodies providing services are linked to formalism, lack of personnel, time restrictions on services, lack of transport, services are not affordable due to the limited financial resources of service recipients.

\section{References}

[1] Common European Guidelines on the Transition from Institutional to Community Based Care (2012). Retrieved from: http: //deinstitutionalisationguide.eu/

[2] A. Guogis, Socialiniụ paslaugụ ekonominiai svertai Lietuvos savivaldybėse. Socialinis darbas 4(1), 66-73 (2005)

[3] C. Xie, J. Hughes, C. Sutcliffe, H. Chester, D. Challis, Promoting personalization in social care services for older people. Journal of gerontological social work 55(3), 218-32 (2012)

[4] E.L. Siegler, S.D. Lama, M.G. Knight, E. Laureano, M.C. Reid, M.C., CommunityBased Supports and Services for Older Adults: A Primer for Clinicians. J. geriatrics 2015 (2015)

[5] Lietuvos Respublikos socialiniụ paslaugụ istatymas (2006), Retrieved from: https://www.e-tar.1t/portal/lt/legalAct/TAR.91609F53E29E

[6] Lietuvos Respublikos socialinès apsaugos ir darbo ministro isakymas "Dèl socialiniụ paslaugụ namuose plètojimo krypčiụ ir stacionariụ globos įstaigų darbo efektyvumo didinimo nuostatu patvirtinimo" (1998) Retrieved from: https://www . e-tar.1t/portal/1t/legalAct/TAR.4E5C43FF9A42

[7] R. Kudukytė-Gasperè, D. Jankauskienè, K. Štaras, Sveikatos ir socialiniu paslaugụ integracija. Atvejo analizė Všı Centro poliklinikoje. Sveikatos politika ir valdymas, 1(4), 127-146 (2012)

[8] Socialiniụ paslaugụ katalogas, Valstybès žinios 43-1570 (2006)

[9] Statistikos departamento informacinis pranešimas. Socialinès paslaugos (2016) Retrieved from: https://osp.stat.gov.lt/informaciniai-pranesimai? articleId $=5178560$ 
[10] Valstybinio audito ataskaita: Ar teikiamos socialinès paslaugos tenkina didejjančius senyvo amžiaus asmenụ poreikius (2015)

[11] L. Žalimienè, Nauji iššūkiai socialinių paslaugụ plètrai - mišrios socialinių paslaugụ rinkos kūrimas. STEPP: socialinė teorija, empirija, politika ir praktika 3, 139-147 (2006)

[12] L. Žalimienė, Socialinės globos paslaugụ pagyvenusiems žmonėms standartizavimas: Lietuvos praktika ir užsienio šaliụ patirtis. Gerontologija 8(1), 44-54 (2007)

[13] G. Kondrataite, Evaluation of the Quality of Public Services in Lithuanian Municipalities. Intellectual Economics 3(15), 393-411 (2012)

[14] L. Žalimienè, D. Skučienè, J. Junevičienè, A. Gataulinas, Profesinè gerové socialinio darbo paslaugu sektoriuje (Lietuvos socialiniụ tyrimų institutas, 2013)

[15] I. Adomaitytė-Subačienè, Socialininụ paslaugụ kokybès standartizavimas Lietuvoje. STEPP: socialinè teorija, empirija, politika ir praktika 11, 54-65 (2015)

[16] L. Žalimienè, Socialinès paslaugos (VU specialiosios psichologijos laboratorija, 2003)

[17] L. Bagdonienè, R. Hopenienè, Paslaugu marketingas ir vadyba (Kaunas: Technolologija, 2005)

[18] M. Išoraité, Socialiniu paslaugu administravimas (Vilnius: UAB Saulè, 2007)

[19] J. Ruškus, N. Mažeikienè, R. Naujanienè, R. Motečienè, D. Dvarionas, Igalinimo samprata socialiniụ paslaugù kontekste. Socialinis darbas: patirtis ir metodai 12(2), 9-43 (2013)

[20] D. Dvarionas, R. Motečienė, J. Ruškus, N. Mažeikienè, R. Naujanienè, Igalinančiụ socialiniụ paslaugų modelis socialinès gerovès politikos kontekste. Filosofija. Sociaologija 25(2), 89-97 (2014)

[21] V. Indrašienè, A. Katkoniené, Pagalbos namuose paslaugụ teikimo vertinimas. Socialinis darbas 10(2), 267-278 (2011)

[22] I. Tamutienè, R. Naujanienè, Senyvo amžiaus asmenụ socialiniụ paslaugụ prieinamumo namuose patirtys. Tiltai 4, 63-78 (2013)

[23] R. Raudeliūnaitè, A. Smalcer, Socialiniụ paslaugụ ị namus teikimo vertinimas paslaugụ gavèjų požiūriu. Socialinisdarbas 15(2), 24-41 (2017)

[24] R. Ulianskienè, O. Vitkūnienè, L. Hitaitè, Integruotu sveikatos priežiūros ir socialiniu paslaugu poreikis ir pletra (2006)

[25] R. Jurkuvienè, S. Audronytè, Lètinėmis ligomis sergančiụ senụ ir pagyvenusiụ žmoniụintegruotụ ilgalaikiụ paslaugụ namuose poreikis. Sveikatos mokslai 5, 1191-1197 (2007)

[26] R. Kudukytè-Gasperè, K. Štaras, Integruotụ slaugos ir psichosocialiniụ paslaugụ poreikis namuose slaugomiems sunkios būklès pacientams ir jụ šeimos nariams. Atvejo analizė všI Centro poliklinikoje. Sveikatos mokslai 25(1), 15-23 (2015)

[27] J.W. Creswell, Research design: Qualitative, Quantative and mixed methods approaches (London: Sage, 2009)

[28] L.C. Johnsosn, Socialinio darbo praktika: bendras požiūris (VU Specialiosio psichologijos laboratorija, 2003)

[29] M. Berg - Weger, Social work and social welfare (London: Routledge, 2010)

[30] V. Coppock, B. Dunn, Understanding social work and mental health (London: Sage, 2010)

[31] A. Guogis, D. Gudelis, Socialiniụ paslaugụ sektoriaus plètros galimybès Lietuvoje. Viešoji politika ir administravimas 12(1), 77-85 (2005) 